\title{
Clinical Follow-Up in People Living with HIV During the COVID-19 Pandemic in Mexico
}

\author{
Ester Gutiérrez-Velilla ${ }^{1,2} \cdot$ Alicia Piñeirúa-Menéndez ${ }^{3} \cdot$ Santiago Ávila-Ríos $^{2} \cdot$ Nancy Patricia Caballero-Suárez $^{2}$ (1)
}

Accepted: 9 February 2022 / Published online: 21 February 2022

(c) The Author(s), under exclusive licence to Springer Science+Business Media, LLC, part of Springer Nature 2022

\begin{abstract}
Clinical follow-up in people living with HIV (PLWH) has individual and public health implications. The objectives of this study were to measure variables related to follow-up failures, identify self-reported reasons to maintain adequate follow-up or for having follow-up failures, and know how the pandemic influenced patients' clinical follow-up. Participants were PLWH receiving HIV-health care at a hospital-based clinic in Mexico City which became an exclusive COVID-19 health service. Participants completed a telephone semi-structured interview and online psychological questionnaires. Lower educational and socioeconomic level, longer times of transportation to the clinic, being attended by different doctors, detectable viral load, having previous dropouts, inadequate antiretroviral adherence, and less HIV knowledge were related to follow-up failures. COVID-19 had a significant negative impact, but it also had positive repercussions for patients with adequate follow-up. These results could help develop effective psychosocial programs and improve healthcare in institutions to facilitate patient retention.
\end{abstract}

Keywords HIV $\cdot$ Clinical follow-up $\cdot$ Mexico $\cdot$ COVID-19 pandemic

\section{Resumen}

El seguimiento clínico en las personas que viven con VIH (PVV) tiene implicaciones individuales y de salud pública. Los objetivos de este estudio fueron medir las variables relacionadas con las fallas en el seguimiento, identificar las razones reportadas para mantener un seguimiento adecuado o para tener fallas en el seguimiento, y conocer cómo la pandemia influyó en el seguimiento clínico de los individuos. Los participantes eran PVV que recibían atención médica para el VIH en una clínica hospitalaria de Ciudad de México que se convirtió en un servicio exclusivo para COVID-19. Los participantes completaron una entrevista semiestructurada por teléfono y cuestionarios psicológicos en línea. El nivel educativo y socioeconómico más bajo, mayor tiempo de transporte a la clínica, falta de continuidad del médico, carga viral detectable, tener abandonos previos, inadecuada adherencia al tratamiento antirretroviral y menor conocimiento del VIH se relacionaron con las fallas en el seguimiento. La pandemia demostró tener un importante impacto negativo, pero también tuvo repercusiones positivas para los pacientes con un seguimiento adecuado. Estos resultados son importantes para desarrollar programas psicosociales eficaces y mejorar la atención sanitaria en las instituciones para facilitar la retención de los pacientes.

Nancy Patricia Caballero-Suárez

nancy.caballero@cieni.org.mx

1 Programa de Maestría y Doctorado en Ciencias Médicas, Odontológicas y de la Salud, Facultad de Medicina, Universidad Nacional Autónoma de México, Ciudad de México, Mexico

2 Centro de Investigación en Enfermedades Infecciosas (CIENI) del Instituto Nacional de Enfermedades Respiratorias (INER), Ciudad de México, Mexico

3 Consorcio de Investigación sobre VIH SIDA TB (CISIDAT), Cuernavaca, Morelos, Mexico

\section{Introduction}

Today, living with HIV has become a chronic condition, which requires a high degree of adherence to medication and clinical follow-up in order to achieve successful health outcomes [1]. Follow-up problems, such as loss to follow-up (LTFU) or poor retention, have been associated with disease progression and the possibility of developing AIDS, increasing the risk of mortality. In addition, follow-up difficulties have been associated with virological failure, which also increases the likelihood of virus transmission. On the other 
hand, poor medical follow-up and poor antiretroviral treatment (ART) adherence may contribute to the development of resistance to ART [2-4]. Despite the importance of clinical follow-up, in Mexico, according to national data, it was estimated that 5 years after linkage to care, only $63 \%$ of PLWH were retained in care [5].

Poor clinical follow-up has been linked to socio-demographic variables such as gender, age, or marital status [6-8]; as well as to clinical determinants of HIV infection; such as viral load and CD4-T cells level [9], or experiencing adverse effects related to ART [10]. Problems with follow-up have also been related to contextual characteristics such as distance to the institution and socioeconomic status [7, 11]. In addition, some characteristics related to care, such as the doctor-patient relationship, have been shown to be relevant to clinical follow-up [12, 13]. Furthermore, relationships with psychological variables such as anxious and depressive symptomatology, perceived stigma, availability of social support, and cognitive evaluation of the disease have also been suggested [14-16].

Until October 2021, the COVID-19 pandemic has caused almost 200 million cases worldwide and more than 4 million deaths. In Mexico, around 2.8 million people have been infected and 240,000 have died [17]. Older adults and people with chronic illnesses, which could include PLWH, especially if they are not under viral suppression, are at greater risk of becoming seriously ill [18-20]. The pandemic has caused economic, employment, and education losses [21, 22]. In addition, the confinement measures established to decrease COVID-19 transmission increased the risk of mental health problems, such as isolation, anxiety, depression, stress, or even suicide [21, 23, 24].

The COVID-19 pandemic has also affected the clinical follow-up of chronically ill people who need continuous monitoring [25]. In the case of people living with HIV, their health care has been affected in different ways. On one hand, due to confinement and social distance, face-to-face appointments were discontinued in many institutions and replaced, -in the best scenario- by remote care via telephone [26, 27]. Also, healthcare personnel's work overload, particularly in infectious disease hospitals, has been evident [27]. Access to ART has been also hampered due to transport issues, which were more difficult due to confinement measures, fear of contagion, or financial stress [28, 29]. Finally, access to routine HIV testing was affected, hindering timely access to health services [26, 29].

Despite the importance of clinical follow-up for people living with HIV, both at the individual level (health outcomes and quality of life) $[3,30]$ and the public health level (costs associated with treatment, HIV transmission, and development of population-based drug resistance) [2, 31], in studies conducted in Latin American populations living with HIV have reported percentages of between 8 and 30\% of patients dropping follow-up completely [32,33]. During the COVID-19 pandemic, this situation may have worsened in the region [27]. Therefore, this study aimed to identify variables associated with failure to follow-up in a population of PLWH regularly seen in a hospital that became COVID19 exclusive. In addition, we were interested in exploring the reasons participants reported for having adequate clinical follow-up as well as for having follow-up failures, and how the pandemic influenced their follow-up.

\section{Methods}

\section{Setting and Participants}

The study was conducted in a hospital-based clinic. The HIV clinic is located inside a tertiary care hospital (the hospital is specialized in treating patients with respiratory diseases) in Mexico City and treats about 1400 adult PLWH. During the COVID-19 pandemic, the hospital was exclusively dedicated to the care of patients with SARS-CoV-2 infection, so medical consultations with HIV patients were canceled, and only face-to-face appointments for ART collection and laboratory tests were available. For this purpose, an organized system of appointments was implemented.

Data collection was conducted from November 2020 to November 2021. We established two groups, people with adequate follow-up and those with follow-up failures. Inclusion criteria for the follow-up failure group were being 18 years old or more, having received HIV care at the study clinic, and having missed at least one appointment for ART collection or laboratory studies during the study period. We were aware that there can be unforeseen events, so we only considered them as follow-up failures in case more than one month had passed since their missed appointment without rescheduling by phone or physically attending the clinic. During the study period, 141 patients were identified with presumed follow-up failures in the databases and contacted to participate in the study. Figure 1 shows the flowchart of how many participants in the group with follow-up failures were located, how many responded to the questionnaires, etc.

Inclusion criteria for those considered as adequate follow-up group were being 18 years old or more and have received HIV care at the study clinic without missing appointments history (of ART collection and laboratory test) during the pandemic. Invitations were sent to all patients who met the inclusion criteria with whom follow-up telephone contact had been maintained in the three months prior to the start of sample collection, and who had previously given their consent to be contacted to participate in research protocols. Of these, 101 patients responded that they were interested in participating and 


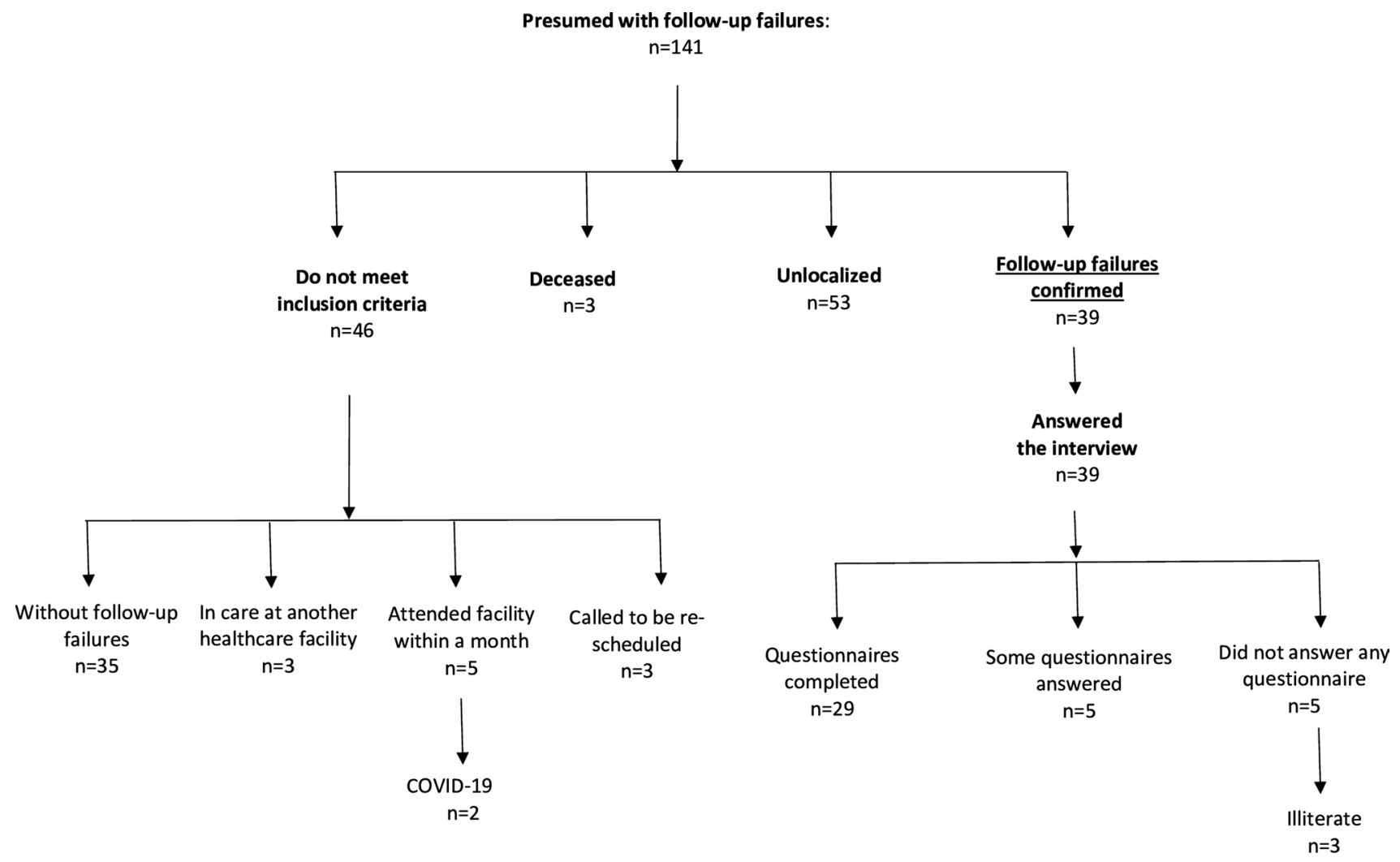

Fig. 1 Flowchart of the search for patients with follow-up failures

Fig. 2 Flowchart of the search for patients with adequate follow-up

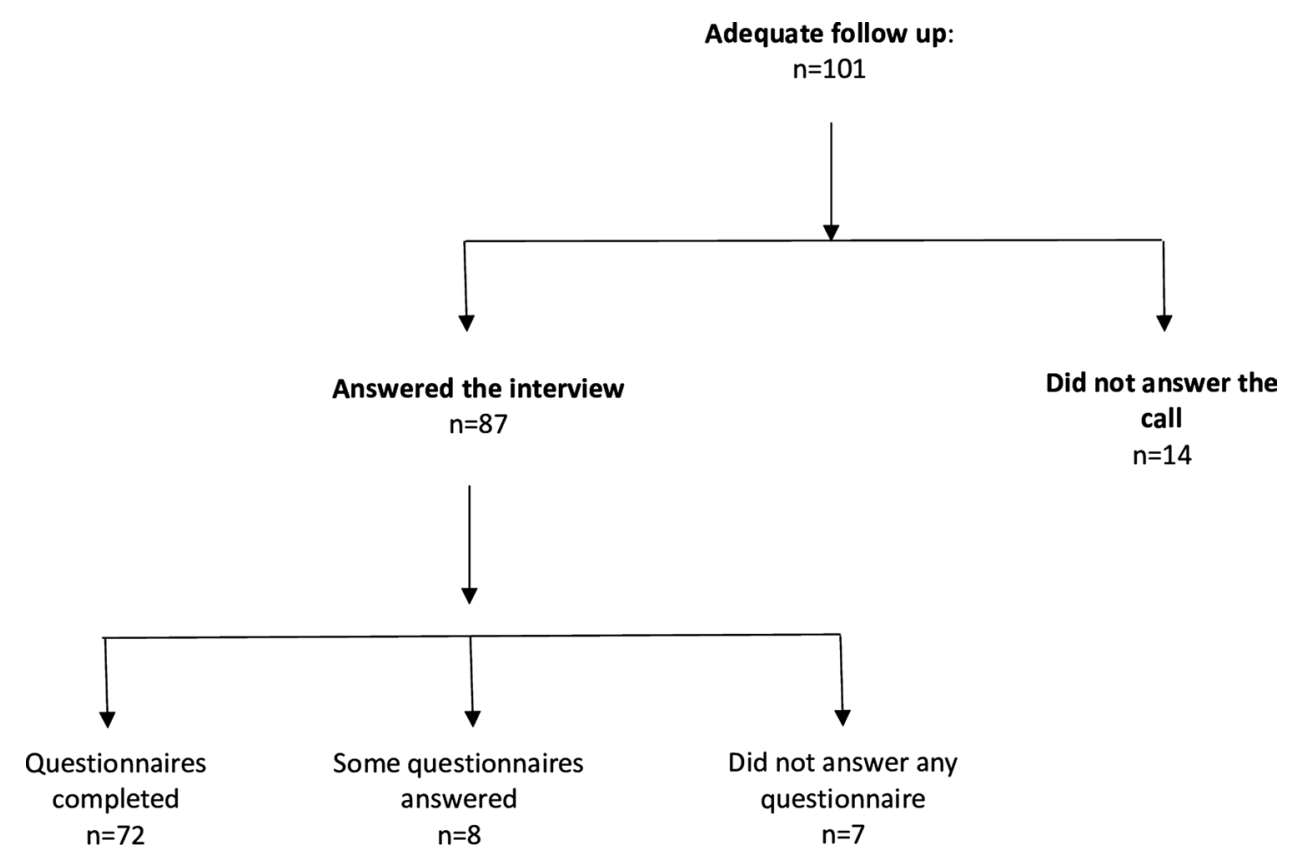

were considered for the adequate follow-up group. Figure 2 shows the flowchart of how many participants in this group were located, how many responded to the questionnaires, etc.

\section{Design}

Cross-sectional study, including quantitative analysis and qualitative content analysis. 


\section{Procedure}

We attempted to contact patients with follow-up failures by telephone on at least 3 different occasions and at different day times. According to the results of this call, they were then definitely classified as confirmed follow-up failures, without follow-up failures (mistakes in the recording of information regarding appointments), in care at another healthcare facility, deceased, or not located. Once classified, if they met the inclusion criteria, they were invited to participate in the study. In case they accepted, a telephonic interview was conducted (at that time, or at another agreed time). After the interview, psychometric self-administered questionnaires were sent via e-mail. In patients with adequate follow-up, as they had previously agreed to participate, a time was arranged to call them by telephone and the interview was conducted, following the same procedure as in the follow-up failure group. In those patients who presented moderate to severe symptoms of anxiety or depression measured by Mexican adaptations of the Beck Anxiety Inventory (BAI) and Beck Depression Inventory (BDI) [34, 35], feedback was given and they were invited to receive attention by a clinical psychologist.

\section{Measures}

\section{Quantitative Data}

Sociodemographic: age, gender, civil status, and educational level, which were asked in the telephone interview.

Clinical: last viral load (undetectable if viral load $<40$ copies $/ \mathrm{mL}$ ) and CD4-T cell count (cells/mL) measurements were collected from clinical database. Time since HIV diagnosis and whether they had adverse effects when starting with their current ART were asked in the telephone interview.

Contextual: socioeconomic level was collected from the clinical file. Social work staff assigns this socioeconomic classification to each patient in care at the clinic to determine the fees for clinical services. Several indicators are considered: occupation, monthly income, type of home (materials, number of bedrooms access to drainage, water, electricity), number of people they live with, and either if they depend financially or if they have economic dependents. Information obtained from this evaluation is used to then classify socioeconomic status in 6 levels, being level $1 \times$ the one with the cheapest fees, and 6 the most expensive one. Distance from the clinic and time invested in transportation were asked in the telephone interview.

Related to care: during the phone interview, they were asked if clinical care was always provided by the same doctor (yes/no) and trust in their doctor was measured with the trust in physician scale [36] in a version adapted and validated in this population, with higher scores indicating a greater confidence in the physician $(\alpha=0.98)$.

Behavioral: in the interview, they were asked whether and with how many people they had shared their diagnosis (disclosure) and whether they had previously abandoned their treatment (previous dropouts). Prescribed and missed doses of ART during the last month were asked to measure the percentage of ART adherence.

Psychological: Psychometric self-administered instruments were answered online by the participants. Anxiety and depression symptoms were measured with the Mexican versions of BAI [34] $(\alpha=0.96)$ and BDI [35] $(\alpha=0.94)$ and substance use risk was measured through alcohol, smoking, and substance involvement screening test (ASSIST) [37]. Stigma was measured with a version of the Berger HIV stigma scale [38] that was adapted and validated in this population, with higher scores indicating higher levels of stigma $(\alpha=0.92)$. Social support was measured with a Mexican adapted version of the medical outcomes studysocial support survey (MOS-SSS) [39] with higher scores indicating higher perceived social support $(\alpha=0.96)$. Beliefs about ART were measured with a version of the beliefs about medicines questionnaire (BMQ) [40] that was adapted and validated in this population, with higher scores indicating a greater perceived need for ART $(\alpha=0.94)$. HIV cognitive evaluation was measured with an adapted version of the cognitive appraisal of health scale (CAHS) [15], higher scores on each subscale indicate assessing HIV as more threatening $(\alpha=0.85)$, more challenging/beneficial $(\alpha=0.84)$, and more controllable $(\alpha=0.40)$. Finally, an HIV/ART knowledge questionnaire, that was developed in the clinic, was applied, counting the number of correct, incorrect, and "I don't know" answers $(\alpha=0.94)$.

\section{Qualitative Data}

Reasons for follow-up failures or for maintaining adequate follow-up were explored: We asked openly why they had missed their appointments in the case of patients with failures in follow-up; and in the case of patients with adequate follow-up, the reasons or motivations for maintaining it.

Impact of COVID-19 on clinical follow-up: We asked openly whether the COVID-19 pandemic affected their follow-up, and in what ways it had (it could have been easier, more difficult, or had both positive and negative aspects).

\section{Data Analysis}

With the quantitative information, flowcharts were made with the results of the search for patients presumed to have follow-up failures or adequate follow-up during the study period. Also, the sociodemographic, clinical, contextual, care-related, behavioral, and psychological variables were 
described in the two groups (with follow-up failures and with adequate follow-up). Frequencies and percentages were established, and medians and standard deviations were obtained in the psychometric instruments. To evaluate whether there were differences in the variables between the group with follow-up failures and the group with adequate follow-up, t-tests (for continuous variables) and chi-squares (for categorical variables) were calculated. The significance level was set at $\mathrm{p}<0.05$.

Regarding qualitative information, data was collected through individual semi-structured interviews. Responses to the open-ended question on reasons for maintaining adequate follow-up/having follow-up failures were transcribed by the principal researcher. The transcripts were then analyzed, identifying key words and main ideas, and emergent categories were established (emerging categories are those that emerge as the information is analyzed or collected). Once the responses were categorized, it was identified which categories shared a common theme (e.g., not developing AIDS, avoiding opportunistic diseases, or staying healthy could be grouped under the theme of "health"). Participants could give several reasons for maintaining adequate follow-up and/or having follow-up failures, so a participant's response could be included in several categories. Subsequently, the information was triangulated with another researcher with expertise in HIV who reviewed the transcripts and independently categorized the responses. If non-agreements were found, they were discussed between the two researchers, with each giving her reasons for including a participant's response in a category until a consensus was reached. Likewise, responses to how the pandemic had affected their clinical follow-up were also transcribed and categorized with aprioristic categories: not affected, did it make it easier, more difficult or were there both positive and negative aspects. Those positive and negative aspects reported by the participants were described too.

\section{Ethical Considerations}

The protocol was approved by the Ethics and Research Committee of the hospital where the study was conducted, under number C02-20. Verbal consent was approved due to the restrictions caused by the COVID-19 pandemic and to preserve the safety of participants and investigators.

\section{Results}

On average, 2.1 call attempts were made to locate 141 patients (approximately $10 \%$ of the population treated at the clinic) who were believed, according to the databases, to have missed at least one appointment during the study period. More than a third $(37.5 \%, n=53)$ of these patients were impossible to locate, and of those located $(n=88)$, $44.3 \%(n=39)$ confirmed that they had a follow-up failure. Of those who after the phone call did not meet the inclusion criteria $(n=46), 35$ were a failure in data capture (they had no appointment, it was not even time to go to collect medication) so were considered "without follow-up failures", 3 were in care at another healthcare facility, and the rest, although they had missed their appointment, they attended facility within a month or called to be re-scheduled, therefore, none of those who did not meet the inclusion criteria were considered to participate in the study. Of the 39 patients with follow-up failures, all answered the telephone interview about socio-demographic, clinical, and contextual data. As for the psychological questionnaires that were sent online, 29 participants answered them completely, five answered all questionnaires except the one about HIV knowledge, three could not read or write so they could not answer them and 2 said they were going to answer them but did not (Fig. 1).

Also, a total of 101 people with adequate follow-up, who had not missed any appointments during the pandemic, were invited to participate. Of these, 87 participants responded to the telephone interview, the other 14 said they wanted to participate but did not respond to the telephone interview call. Of those who did respond to the sociodemographic interview, 72 completed the psychological questionnaires, 8 answered some questionnaires, and 7 did not answer any of the questionnaires (Fig. 2).

\section{Differences Between Adequate Follow-Up vs. Follow-Up Failures}

No significant differences were found between those who participated in the study and the patients who were not located or who did not meet the inclusion criteria in any of the sociodemographic, clinical and contextual variables that could be retrieved from the databases. Regarding sociodemographic variables, there were more women in the group with follow-up failures (17.9\% vs. $9.2 \%)$, although the difference was not significant, $\chi_{(1)}^{2}=1.967, p>0.05$; and the educational level was lower in this group (41.0\% of participants who had a secondary level or less vs. $14.9 \%$ ); in this case, the difference was significant, $\chi_{(1)}^{2}=10.340 \mathrm{p}<0.001$.

Regarding clinical variables, the percentage of participants who had undetectable viral load was lower in the group with follow-up failures ( $71.8 \%$ vs. $95.4 \chi_{(1)}^{2}=14.310$ $\mathrm{p}<0.001)$. The median T-CD4 cell count was lower in this group ( 381 cells $/ \mathrm{mm}^{3}$ vs. 484 cells $/ \mathrm{mm}^{3}$ ), although not significant, $\mathrm{t}_{(124)}=1.525 \mathrm{p}>0.05$. Also, a higher proportion of patients with follow-up failures reported having experienced side effects related to ART they were currently taking (51.3\% vs. $42.5 \%)$, although the difference was also not significant, $\chi_{(1)}^{2}=0.833 \mathrm{p}>0.05$. 
On contextual variables, the percentage of patients in the lowest socioeconomic levels $(1 \times$ or 1$)$, was higher in the group with follow-up failures $(61.5 \%$ versus $36.8 \%$ $\left.\chi_{(1)}^{2}=6.684 \mathrm{p}<0.05\right)$. Also, the median time that patients spent arriving at the clinic was longer in this group (75 $\mathrm{min}$ vs. $\left.40 \mathrm{~min}, \mathrm{t}_{(124)}=-3.260 \mathrm{p}<0.001\right)$.

Regarding the variables related to care, in the group with follow-up failures, compared to the adequate followup group, a higher proportion reported that their HIV care was not always provided by the same physician $(41.0 \%$ vs. $\left.20.7 \% \chi_{(1)}^{2}=5.652, \mathrm{p}<0.05\right)$. On the other hand, in the TPS questionnaire, the level of trust in the physician was slightly lower in the group with follow-up failures, although the difference was not significant, $\mathrm{t}_{(112)}=1.028, \mathrm{p}>0.05$.

As for behavioral variables, in the group with follow-up failures, a higher proportion had previously dropped out of follow-up (27.3\% vs. $8.0 \%)$ the difference being significant, $\chi_{(1)}^{2}=10.858, \mathrm{p}<0.001$, and a higher proportion had inadequate adherence to ART ( $41.0 \%$ vs. $8.0 \%)$, and the difference was also significant $\chi_{(1)}^{2}=19.628, p<0.001$. Broad characteristics of both groups can be found in Table 1 .

In the psychometric questionnaires, the differences were generally not significant, possibly due to the small size of the group with follow-up failures (some questionnaires had only been completed by 29 participants). It was observed that in the group with follow-up failures a higher proportion of participants had moderate or severe anxiety symptoms (38.2\% vs. $27.3 \%$ ), although the difference was not significant, $\chi_{(1)}^{2}=1.334 \mathrm{p}>0.05$. For depressive symptoms the opposite was found, participants with follow-up failures had moderate or severe symptoms in lower proportion (17.6\% vs. $26.0 \%$ ), although the difference was not significant either, $\chi_{(1)}^{2}=0.912, p>0.05$. In the remaining psychological variables (stigma, social support, and ART perceived necessity), no significant differences were found either, except in the cognitive evaluation variable, in the control subscale, the group with follow-up failures had a lower score, indicating a perception of less controllability of the disease, and the difference was significant in this case, $\mathrm{t}_{(112)}=1.988, \mathrm{p}<0.05$. In addition, in the HIV knowledge questionnaire, it was found that the group with follow-up failures had a lower mean of correct answers (37.6 vs. $\left.44.3, \mathrm{t}_{(100)}=3.981 \mathrm{p}<0.001\right)$ and a higher mean of incorrect answers (7.8 vs. $3.8, \mathrm{t}_{(100)}=-3.404$ $\mathrm{p}<0.001)$ and answers that they did not know (4.5 vs. 1.9 , $\left.\mathrm{t}_{(100)}=-2.576 \mathrm{p}<0.05\right)$, the differences being significant. Participants' scores on psychometric instruments are shown in Table 2.

\section{Reported Reasons for Having Follow-Up Failures and for Having Adequate Follow-Up}

People with follow-up failures reported on average 3.5 reasons for having had these problems. Most commonly they reported 2 reasons $(n=14)$, then $3(n=10)$ and 4 reasons $(\mathrm{n}=5)$ and the highest number of reasons reported was 9 $(\mathrm{n}=2)$. Several reported reasons had to do with contextual difficulties, such as having financial problems, social support-related issues, having suffered violence and, the most reported in this theme, having to care for a family member. Other reasons had to do with health services, the most reported in this theme was problems with contacting the institution, other reasons reported included problems with paperwork, disagreement with schedules and waiting times, being transferred from one institution to another, and/or health insurance issues. Other reasons had to do with structural barriers such as difficulty with transportation, distance to the clinic, and the most commonly reported, difficulty in missing work (especially due to pandemic situation). Some others reported having health problems that made it difficult to attend their appointments, some of them due to COVID. Another theme had to do with psychological issues, such as having emotional problems, problems with drug use, or even denying HIV diagnosis because they were asymptomatic or "felt well". Some other reasons reported were due to a lack of information about ART (think they don't need it) and mostly, about ART collection procedures or blood sampling procedures during the pandemic and the conversion to a COVID-19 exclusive hospital. In the theme of other reasons, still having treatment available (even though they should have finished it by that moment, according to clinic estimations) was the most reported, other reasons included forgetfulness and pandemic-related reasons such as fear of infection, changes in routine and organization of services and lockdown measures. The frequency with which these reasons were mentioned and some exemplar quotes are shown in Table 3.

Also, participants with adequate follow-up answered the question of what motivated them not to miss their appointments and reported some reasons that had to do with social aspects, such as being able to take care of their children, being present for their family, plans they had to fulfill and the most reported in this category, being able to have a normal life. Also, some reasons had to do with health services such as wishing to continue to receive ART, having received good treatment from their doctors, and/or wanting to continue in the same institution due to satisfaction with services received. The most reported reasons had to do with health issues, mostly, staying healthy, but also avoiding opportunistic diseases, avoiding the development of AIDS (whether they had had it before or not), fear to die, being able to work and/or study and have felt good up to that point thanks to adequate follow-up. The remaining reasons were classified as other and included being motivated to be able to see their viral load and T-CD4 cell studies; other participants were aware and grateful to have ART for free, knowing that it is usually an expensive drug. Others reported that being 
Table 1 Comparison of variables between adequate follow-up and with follow-up failures

\begin{tabular}{|c|c|c|c|c|}
\hline & Adequate follow-up $(n=87)$ & Follow-up failures $(\mathrm{n}=39)$ & Statistical test & $\mathrm{p}$ value \\
\hline \multicolumn{5}{|l|}{ Sociodemographic } \\
\hline \multicolumn{5}{|l|}{ Gender \% (n) } \\
\hline Women & $9.2(8)$ & $17.9(7)$ & \multirow[t]{2}{*}{$\chi_{(1)}^{2}=1.967$} & \multirow[t]{2}{*}{0.161} \\
\hline Men & $90.8(79)$ & $82.1(32)$ & & \\
\hline \multicolumn{5}{|l|}{ Age } \\
\hline Mean (SD) & $43.87(10.192)$ & $41.33(8.241)$ & $\mathrm{t}_{(124)}=1.368$ & 0.174 \\
\hline \multicolumn{5}{|l|}{ Civil status \% (n) } \\
\hline Single & $71.3(62)$ & $64.1(25)$ & \multirow[t]{5}{*}{$\chi_{(4)}^{2}=5.716$} & \multirow[t]{5}{*}{0.221} \\
\hline Married & $10.3(9)$ & $5.1(2)$ & & \\
\hline In common law & $13.8(12)$ & $25.6(10)$ & & \\
\hline Separated/divorced & $4.6(4)$ & $2.6(1)$ & & \\
\hline Widowed & - & $2.6(1)$ & & \\
\hline \multicolumn{5}{|l|}{ Educational level \% (n) } \\
\hline Secondary education or less & $14.9(13)$ & $41.0(16)$ & \multirow[t]{2}{*}{$\chi_{(1)}^{2}=10.340$} & \multirow[t]{2}{*}{$<0.001$} \\
\hline High school or more & $85.1(74)$ & $59.0(23)$ & & \\
\hline \multicolumn{5}{|l|}{ Clinical } \\
\hline \multicolumn{5}{|l|}{ Viral load: undetectable \% ( $n$ ) } \\
\hline Yes & $95.4(83)$ & $71.8(28)$ & \multirow[t]{2}{*}{$\chi_{(1)}^{2}=14.310$} & \multirow[t]{2}{*}{$<0.001$} \\
\hline No & $4.6(4)$ & $28.2(11)$ & & \\
\hline \multicolumn{5}{|l|}{ CD4-T cell count } \\
\hline Median (IQR) & $484(326-628)$ & $381(248-532)$ & $\mathrm{t}_{(124)}=1.525$ & 0.130 \\
\hline \multicolumn{5}{|l|}{ Time since diagnosis (months) } \\
\hline Median (IQR) & $97.0(66-150)$ & $116.0(79-162)$ & $\mathrm{t}_{(124)}=-0.800$ & 0.425 \\
\hline \multicolumn{5}{|l|}{ Adverse effects of $A R T \%(n)$} \\
\hline Yes & $42.5(37)$ & $51.3(20)$ & \multirow[t]{2}{*}{$\chi_{(1)}^{2}=0.833$} & \multirow[t]{2}{*}{0.361} \\
\hline No & $57.5(50)$ & $48.7(19)$ & & \\
\hline \multicolumn{5}{|l|}{ Contextual } \\
\hline \multicolumn{5}{|l|}{ Socioeconomic level \% ( $n$ ) } \\
\hline $1 \times$ or 1 & $36.8(32)$ & $61.5(24)$ & & \\
\hline 2 or higher & $63.2(55)$ & $38.5(15)$ & $\chi_{(1)}^{2}=6.684$ & 0.010 \\
\hline Distance to the clinic $(\mathrm{km})$ & & & & \\
\hline Median (IQR) & $22.0(15.7-31.1)$ & $26.1(15.8-37.0)$ & $\mathrm{t}_{(124)}=-1.763$ & 0.080 \\
\hline Time of transportation (minu & & & & \\
\hline Median (IQR) & $40(28-71)$ & $75(50-120)$ & $\mathrm{t}_{(124)}=-3.260$ & $<0.001$ \\
\hline Related to care & & & & \\
\hline Always attended by same doc & & & & \\
\hline Yes & $79.3(69)$ & $59.0(23)$ & $\chi_{(1)}^{2}=5.652$ & 0.017 \\
\hline No & $20.7(18)$ & $41.0(16)$ & & \\
\hline Trust in the doctor (TPS) & & & & \\
\hline Score mean $(7-35)$ & 30.4 & 28.7 & $\mathrm{t}_{(112)}=1.028$ & 0.306 \\
\hline Behavioral & & & & \\
\hline Disclosure \% (n) & & & & \\
\hline$\leq 2$ persons & $18.4(16)$ & $23.1(9)$ & $\chi_{(1)}^{2}=0.372$ & 0.542 \\
\hline$>2$ persons & $81.6(71)$ & $76.9(30)$ & & \\
\hline$N^{o}$ person who knows diagno & & & & \\
\hline Mean (SD) & $11.1(16.155)$ & $8.6(11.212)$ & $\mathrm{t}_{(124)}=0.854$ & 0.395 \\
\hline Previous dropouts \% (n) & & & & \\
\hline Yes & $8.0(7)$ & $27.3(12)$ & $\chi_{(1)}^{2}=10.858$ & $<0.001$ \\
\hline No & $92.0(80)$ & $72.7(27)$ & & \\
\hline
\end{tabular}


Table 1 (continued)

\begin{tabular}{|c|c|c|c|c|}
\hline & Adequate follow-up $(\mathrm{n}=87)$ & Follow-up failures $(\mathrm{n}=39)$ & Statistical test & $\mathrm{p}$ value \\
\hline \multicolumn{5}{|l|}{ Adherence \% ( $n)$} \\
\hline$<95 \%$ (inadequate) & $8.0(7)$ & $41.0(16)$ & $\chi_{(1)}^{2}=19.628$ & $<0.001$ \\
\hline$>95 \%$ (adequate) & $92.0(80)$ & $59.0(23)$ & & \\
\hline
\end{tabular}

$S D$ standard deviation, $I Q R$ interquartile range

Table 2 Comparison of psychological variables between adequate follow-up and with follow-up failures

\begin{tabular}{|c|c|c|c|c|}
\hline & $\begin{array}{l}\text { Adequate follow-up } \\
(\mathrm{n}=77)\end{array}$ & $\begin{array}{l}\text { Follow-up failures } \\
(\mathrm{n}=34)\end{array}$ & Statistical test & $\mathrm{p}$ value \\
\hline \multicolumn{5}{|l|}{ Anxiety \% (n) } \\
\hline Minimum or mild & $72.7(56)$ & $61.8(21)$ & \multirow[t]{2}{*}{$\chi_{(1)}^{2}=1.334$} & \multirow[t]{2}{*}{0.248} \\
\hline Moderate or severe & $27.3(21)$ & $38.2(13)$ & & \\
\hline \multicolumn{5}{|l|}{ Depression \% (n) } \\
\hline Minimum or mild & $74.0(57)$ & $82.4(28)$ & \multirow[t]{2}{*}{$\chi_{(1)}^{2}=0.912$} & \multirow[t]{2}{*}{0.340} \\
\hline Moderate or severe & $26.0(20)$ & $17.6(6)$ & & \\
\hline \multicolumn{5}{|l|}{ Risk of substance abuse } \\
\hline None & $41.6(32)$ & $38.2(13)$ & \multirow[t]{3}{*}{$\chi_{(2)}^{2}=0.130$} & \multirow[t]{3}{*}{0.937} \\
\hline One substance & $23.4(18)$ & $23.5(8)$ & & \\
\hline \multirow[t]{3}{*}{ Two or more substance } & $35.1(27)$ & $38.2(13)$ & & \\
\hline & $\begin{array}{l}\text { Adequate follow-up } \\
(\mathrm{n}=80)\end{array}$ & $\begin{array}{l}\text { Follow-up failures } \\
(\mathrm{n}=34)\end{array}$ & & \\
\hline & Mean score & Mean score & & \\
\hline \multicolumn{5}{|l|}{ Stigma } \\
\hline Internalized stigma (4-16) & 7.19 & 7.88 & $\mathrm{t}_{(112)}=1.060$ & 0.291 \\
\hline Concerns about disclosure (5-20) & 13.66 & 12.15 & $\mathrm{t}_{(112)}=1.902$ & 0.060 \\
\hline Negative self-image (6-24) & 9.49 & 9.79 & $\mathrm{t}_{(112)}=-0.398$ & 0.692 \\
\hline Concerns public HIV attitudes (5-20) & 12.39 & 11.74 & $\mathrm{t}_{(112)}=0.840$ & 0.403 \\
\hline Total $(20-80)$ & 42.72 & 41.56 & $\mathrm{t}_{(112)}=0.483$ & 0.630 \\
\hline \multicolumn{5}{|l|}{ Social support } \\
\hline Emotional (12-60) & 47.79 & 44.06 & $\mathrm{t}_{(112)}=1.417$ & 0.159 \\
\hline Tangible (4-20) & 15.84 & 14.74 & $\mathrm{t}_{(112)}=1.168$ & 0.245 \\
\hline Total (16-80) & 63.75 & 58.79 & $\mathrm{t}_{(112)}=1.479$ & 0.142 \\
\hline \multicolumn{5}{|l|}{ ART perceived necessity } \\
\hline Score $(5-25)$ & 22.06 & 20.79 & $\mathrm{t}_{(112)}=1.291$ & 0.199 \\
\hline \multicolumn{5}{|l|}{ HIV cognitive evaluation } \\
\hline Threat (5-30) & 12.24 & 12.26 & $\mathrm{t}_{(112)}=-0.024$ & 0.981 \\
\hline Challenge (3-15) & 9.33 & 9.15 & $\mathrm{t}_{(112)}=0.205$ & 0.838 \\
\hline \multirow[t]{3}{*}{ Control (2-10) } & 8.16 & 7.29 & $\mathrm{t}_{(112)}=1.988$ & 0.049 \\
\hline & $\begin{array}{l}\text { Adequate follow-up } \\
\mathrm{n}=(73)\end{array}$ & $\begin{array}{l}\text { Follow-up failures } \\
\mathrm{n}=(29)\end{array}$ & & \\
\hline & Mean & Mean & & \\
\hline \multicolumn{5}{|l|}{ HIV and ART knowledge ${ }^{a}$} \\
\hline Correct answers & 44.26 & 37.66 & $\mathrm{t}_{(100)}=3.981$ & $<0.001$ \\
\hline Incorrect answers & 3.82 & 7.79 & $\mathrm{t}_{(100)}=-3.404$ & $<0.001$ \\
\hline "I don't know" answers & 1.92 & 4.55 & $t_{(100)}=-2.576$ & 0.011 \\
\hline
\end{tabular}

a50 questions; $S D$ standard deviation, $I Q R$ interquartile range 
Table 3 Reasons reported for having follow-up failures $(n=39)$

\begin{tabular}{|c|c|c|c|}
\hline Theme & Categories & $\mathrm{f}$ & Example quotes \\
\hline Contextual & $\begin{array}{l}\text { Economic problems } \\
\text { Social support } \\
\text { Having to take care of a family member } \\
\text { Violence }\end{array}$ & $\begin{array}{l}4 \\
1 \\
9 \\
2\end{array}$ & $\begin{array}{l}\text { "I had to move to the village, I had financial problems because I } \\
\text { became unemployed" } \\
\text { "...then my mother became ill with cancer, I had to take care of her } \\
\text { and I could not attend appointments .... she finally passed away" }\end{array}$ \\
\hline Health services & $\begin{array}{l}\text { Paperwork } \\
\text { Schedules and waiting times } \\
\text { Problems to contact the institution } \\
\text { Referral from one institution to another } \\
\text { Insurance issues }\end{array}$ & $\begin{array}{l}4 \\
2 \\
12 \\
1 \\
3\end{array}$ & $\begin{array}{l}\text { "I missed the appointment... I tried to reschedule it but they were not } \\
\text { answering the phone" } \\
\text { "... as I got a job I was registered in the insurance without notifica- } \\
\text { tion, so I could no longer be treated in this institution and I had to be } \\
\text { treated in another center but I didn't know it" }\end{array}$ \\
\hline Barriers & $\begin{array}{l}\text { Transport } \\
\text { Distance to the clinic } \\
\text { Work }\end{array}$ & $\begin{array}{l}5 \\
3 \\
16\end{array}$ & $\begin{array}{l}\text { "...I had to move to Oaxaca and it is very difficult to travel to the city" } \\
\text { "I couldn't let them fire me from this job anymore, from Monday to } \\
\text { Saturday I couldn't miss it" }\end{array}$ \\
\hline Health & Having health problems & 10 & $\begin{array}{l}\text { "I was hospitalized in the carcinology hospital, I could not go to the } \\
\text { appointment for laboratory studies" }\end{array}$ \\
\hline Psychological & $\begin{array}{l}\text { Emotional problems } \\
\text { Drugs } \\
\text { Believe not having HIV (that have been cured) }\end{array}$ & $\begin{array}{l}6 \\
2 \\
2\end{array}$ & $\begin{array}{l}\text { "I had problems with my wife, she left me and I got psychologically } \\
\text { affected" } \\
\text { "...many days when I drank alcohol I stopped taking the TAR, I had } \\
\text { plenty, and I didn't need to go for more" }\end{array}$ \\
\hline Lack of information & $\begin{array}{l}\text { About ART } \\
\text { About attention procedures }\end{array}$ & $\begin{array}{l}1 \\
12\end{array}$ & $\begin{array}{l}\text { "They always called me to schedule appointments, I didn't know I had } \\
\text { to call, I was just waiting for them to do it" }\end{array}$ \\
\hline Other & $\begin{array}{l}\text { Forgetting } \\
\text { Others } \\
\text { Remaining ART (taking it wrong, incorrectly } \\
\text { scheduled appointments...) } \\
\text { Fear of pandemic } \\
\text { Changes produce by pandemic (routine, lock- } \\
\text { down measures...) }\end{array}$ & $\begin{array}{l}6 \\
5 \\
16 \\
3 \\
8\end{array}$ & $\begin{array}{l}\text { "...then months passed and I simply forgot to schedule the appoint- } \\
\text { ment" } \\
\text { "... and since I still had several pills, I didn't try to make an appoint- } \\
\text { ment" } \\
\text { "... I was afraid of going out and being infected, I didn't go out any- } \\
\text { where..." } \\
\text { "... administrative procedures were stopped because of the pandemic" }\end{array}$ \\
\hline
\end{tabular}

$f$ frequency of reporting

informed, aware and responsive motivated them to maintain adequate follow-up. Finally, others found motivation in being able to take care of themselves so as not to acquire COVID-19. Table 4 resumes the frequency with which these reasons were mentioned and some exemplar quotes.

\section{Impact of the Pandemic in Clinical Follow-Up}

In the group with follow-up failures, the majority reported that clinical follow-up had been more difficult during the pandemic, and only one person found it easier. However, in the group with adequate follow-up, up to $33 \%$ found the follow-up easier and $20 \%$ found both positive and negative things, see Table 5.

Regarding the reasons why they found the follow-up easier, they reported that clinical visits took less time since an appointment system was implemented that was not previously used. This, in turn, meant that there were fewer people in the clinic, reducing the risk of COVID-19 contagion. In addition, the ART collection procedure was easier because the institution called them personally to make the appointments, a procedure which was not done in the previous years, as patients attended without an appointment. It was also reported on several occasions that they had to make fewer visits to the clinic because they made laboratory studies and received medicine on the same day, and they were given medicine for more months.

The reported negative aspects that the pandemic brought, and that made clinical follow-up difficult, were the lockdown measures, not being able to miss work, both because they had fewer job opportunities and could not refuse to take them because they had higher economic needs. The most reported reason was that the follow-up was limited since they did not have face-to-face consultations with their attending physician and that they even had to go to private doctors with whom they reported a lack of trust. They also complained that previous to the COVID19 pandemic they were seen by doctors of different specialties (pneumologist, ophthalmologist, etc.), and in the same clinic they were tested for other conditions and received comprehensive treatment, whereas now they were only tested for viral load and CD4. Some reported difficulty in 
Table 4 Reasons reported for having adequate clinical follow-up $(n=87)$

\begin{tabular}{|c|c|c|c|}
\hline Theme & Category & $\mathrm{f}$ & Example quotes \\
\hline Social & $\begin{array}{l}\text { Be able to take care of children } \\
\text { Be there for their family } \\
\text { Be able to live a normal life } \\
\text { Plans to be fulfilled }\end{array}$ & $\begin{array}{l}2 \\
6 \\
9 \\
5\end{array}$ & $\begin{array}{l}\text { "I want to be well for my family and not worry them" } \\
\text { "I have a lot of things to do, plans and goals to accomplish" }\end{array}$ \\
\hline Health services & $\begin{array}{l}\text { Be able to continue receiving ART } \\
\text { Having received good treatment from their physician } \\
\text { Continue to receive care at this institution } \\
\text { Services received at this institution }\end{array}$ & $\begin{array}{l}3 \\
4 \\
4 \\
12\end{array}$ & $\begin{array}{l}\text { "I really appreciate the efforts of the doctors who saved my } \\
\text { life, I was given up for dead..." } \\
\text { "I have always received very good treatment at the clinic, the } \\
\text { attention is excellent" "I feel very grateful" }\end{array}$ \\
\hline Health & $\begin{array}{l}\text { Be in good health } \\
\text { Avoid getting sick } \\
\text { Not to develop AIDS } \\
\text { Not to have AIDS again } \\
\text { Unwillingness to die } \\
\text { Be able to work or study } \\
\text { Continue to feel good }\end{array}$ & $\begin{array}{l}51 \\
8 \\
4 \\
11 \\
19 \\
4 \\
12\end{array}$ & $\begin{array}{l}\text { "...lead a healthy life" "I have an interest in being healthy" } \\
\text { "I do it because I'm afraid of what comes with the disease, } \\
\text { having opportunistic diseases or worsening my health" } \\
\text { "so far I haven't gotten sick or been hospitalized and that } \\
\text { motivates me to keep going" }\end{array}$ \\
\hline Other & $\begin{array}{l}\text { Other } \\
\text { Be able to see laboratory studies (VL, CD4-T cells } \\
\text { count...) } \\
\text { Aware they have free ART } \\
\text { Be informed/be aware } \\
\text { Responsibility/discipline } \\
\text { Beware of COVID }\end{array}$ & $\begin{array}{l}16 \\
6 \\
6 \\
14 \\
13 \\
2\end{array}$ & $\begin{array}{l}\text { "...it motivates me to be able to see how my CD4 count is" } \\
\text { "I am aware that drugs are very expensive and here I get } \\
\text { them for free" } \\
\text { "taking ART, going to my studies is a whole...it's my respon- } \\
\text { sibility" } \\
\text { "I want to be well... so that if I get COVID it won't be so } \\
\text { harmful" }\end{array}$ \\
\hline
\end{tabular}

$f$ frequency of reporting

Table 5 Impact of the pandemic in clinical follow-up

\begin{tabular}{lll}
\hline & $\begin{array}{l}\text { Adequate follow-up } \\
(\mathrm{n}=30) \%(\mathrm{n})\end{array}$ & $\begin{array}{l}\text { Follow-up } \\
\text { failures }(\mathrm{n}=39) \\
\%(\mathrm{n})\end{array}$ \\
\hline Not affected & $20.0(6)$ & $23.1(9)$ \\
Easier & $33.3(10)$ & $2.6(1)$ \\
More difficult & $26.7(8)$ & $69.2(27)$ \\
$\begin{array}{l}\text { It had both positive and } \\
\text { negative things }\end{array}$ & $20.0(6)$ & $5.1(2)$ \\
\hline
\end{tabular}

being able to communicate with the institution, problems with transportation, being afraid of COVID-19 contagion, having become ill with COVID-19 or that a family member was ill or died due to COVID-19, feeling emotionally affected, having been referred to another institution because of the pandemic, and feeling that health attention was slower and priority was given to COVID-19. Positive and negative things of pandemic reported by participants and some example quotes are shown in Table 6.

\section{Discussion}

In this study, locating patients with follow-up failures and getting them to answer the questionnaires was challenging. This is probably because they are a hard-to-reach population added to the fact that, during the pandemic, more difficulties have been reported in achieving participation in research studies [41, 42]. Another observed issue was that; from the patients that initially were presumed to have problems with follow-up, many had been misclassified as such. This issue has been reported in other studies [43] suggesting a need for improved patient registration and monitoring systems.

When analyzing the differences between the two groups, in the follow-up failures group, a higher proportion of people were found to have lower levels of education, which could be related to less information about HIV and ART, as well as a higher probability of unemployment, low income, and difficulties in maintaining clinical follow-up [7, 10, 44]. This is confirmed by the lower socio-economic status of people in the follow-up failures group. In addition, although on average both groups lived about the same distance to the clinic, those in the follow-up failures group reported taking longer to get there, probably due to lack of access to efficient transport systems. In terms of clinical variables, the proportion of patients with viral suppression was considerably lower in 
Table 6 Positive and negative reported aspects of the pandemic impacting clinical follow-up

\begin{tabular}{|c|c|c|}
\hline Positive $(\mathrm{n}=19)$ & $\mathrm{f}$ & Example quotes \\
\hline Attended faster & 10 & \multirow{4}{*}{$\begin{array}{l}\text { "it's much better than before, it's faster because there are fewer people..." } \\
\text { "It has made it easier for me, they give me more medicine and so I have to go less } \\
\text { often... I have to ask for less permission at work" }\end{array}$} \\
\hline Fewer visits, more ART given & 7 & \\
\hline $\begin{array}{l}\text { Easier ART collection procedure (they were called to } \\
\text { make appointments) }\end{array}$ & 6 & \\
\hline Fewer people at the clinic & 3 & \\
\hline Negative $(n=43)$ & $\mathrm{f}$ & Example quotes \\
\hline Lockdown measures, not being able to leave town & 3 & \multirow{13}{*}{$\begin{array}{l}\text { "the economic issue got complicated and I can't miss work to go to the clinic" } \\
\text { "I had a change of ART and although the doctor tries to be aware of it, the follow- } \\
\text { up she can give me is worse" "there is no face-to-face follow-up" } \\
\text { "I used to have more studies done, bones and others... now only viral load" } \\
\text { "I had COVID and had to wait until the test was negative to go to the clinic" } \\
\text { "it is much more difficult to have a proper follow-up, everything is focused on } \\
\text { COVID and the care of the rest of the diseases has been strongly delayed" }\end{array}$} \\
\hline Cannot skip work (less work, need the money more) & 11 & \\
\hline Limited follow-up (no face-to-face) & 15 & \\
\hline Having to go to private doctors & 3 & \\
\hline Fewer studies for other conditions & 7 & \\
\hline Communication problems with the clinic & 6 & \\
\hline Transport problems & 3 & \\
\hline Fear or panic & 4 & \\
\hline Being sick of COVID & 6 & \\
\hline Family members sick of COVID and/or deceased & 3 & \\
\hline Emotionally affected & 2 & \\
\hline Referred to another institution because of the pandemic & 1 & \\
\hline Slower health attention and priority given to COVID-19 & 5 & \\
\hline
\end{tabular}

$f$ frequency of reporting

the group with follow-up failures, demonstrating the clinical consequences of inadequate follow-up [6, 9]. Consistent with what has been found in other studies [45-47], the group with follow-up failures reported in a greater proportion that their physician was not the same at every consultation, emphasizing the role of the doctor-patient relationship and the importance of a sense of continuity. In addition, in the group with follow-up failures, there was a higher proportion of participants who had a history of previous dropouts and inadequate adherence to ART, something that has been reported in several previous studies [45, 48].

Although the rest of the variables were not statistically significant, possibly due to the small sample size of the group of patients with follow-up failures, some differences were found that are worth highlighting. There appear to be more women in the group with follow-up failures, contrary to what is reported in other studies, but this could be due to the social inequalities that women still face in Mexico, as well as being the majority of those responsible for household activities and care of family members [49]. Also, participants with follow-up failures were slightly more prone to have disclosed their diagnosis with fewer people, although only the number of people to whom the diagnosis had been disclosed was measured and not who those people were, it would be useful for future studies to explore into this variable in more detail.

As regards psychological variables, in general, the differences were not significant. One possible explanation for this is the lack of control over the response to the questionnaires since they were answered online in their homes. Particularly, the people in the group with follow-up failures were reluctant to answer the questionnaires, and they had to be reminded several times, which could have made them respond in a noncommittal manner. Almost the only variable that had a significant difference between groups was a subscale of the HIV cognitive evaluation scale. The group with follow-up failures assessed the disease as less controllable, which is consistent with what has been reported in the literature suggesting that a perception of low controllability influences adjustment to the disease and is related to inadequate levels of adherence to treatment [15]. However, the reliability of this subscale is the only one that was not satisfactory, so this result should be taken with caution. At the same time, knowledge about HIV and ART, even with the small sample size, showed to be significantly different between the two groups: those with follow-up failures had fewer correct answers and more incorrect or "don't know" answers; underlining the importance of psychoeducation in PLWH to ensure adequate medical follow-up behaviors.

Of the variables that were not found to have significant differences, we highlight the results for the variables related to emotional symptoms. A higher proportion of patients with anxiety symptoms was found in the group with follow-up failures, although this did not occur when analyzing depressive symptoms. This may be because the follow-up failures were considered after absences of one 
month after their appointment (a relatively short period compared to other studies where absences are as long as one year) [4]. In this case, the situations of follow-up failures could be related to specific events causing anxiety in these patients, and not so much to a long period of emotional distress. Another possible explanation, which has been reported in other studies, is that people with depression may have a closer follow-up, due to mental health care, which makes it more likely to continue with adequate follow-up [45].

Participants with follow-up failures reported the reasons why this failed to occur. The most frequently reported reason was related to work obligations, and this became more important during the pandemic, as job opportunities were fewer and individuals needed the money more $[23,28]$. The next most reported reasons were having problems communicating with the institution and lack of information about procedures, which were also related to the pandemic situation, since previously it was not necessary to communicate via telephone with the institution to schedule appointments nor were there so many doubts about procedures, something that occurred due to the change in the organization, since the hospital became an exclusive healthcare facility for COVID19 patients and access to PLWH became more difficult. This was reported despite the great efforts made by the institution to disseminate information by different means (mailings, social networks, posters, etc.) and to improve the telephone communication systems. Other reasons had to do with caring for family members, emotional problems, confinement measures, or changes due to the pandemic (at the level of routines, organizations, etc.). It is important to mention that the institution has a record of the amount of medication given to patients, as well as the times when they must come to pick up medication, to avoid being out of stock. Even so, another widely reported reason for not attending their appointments had to do with still having ART available, this may again be due to deficiencies in the registration system, or failure of patients to take the medication, making it last longer than it should.

Reasons reported for maintaining adequate clinical follow-up had to do mainly with health, as maintaining good health, avoiding opportunistic infections, or developing AIDS (either because they had had it before or because they did not want to get it) or not wanting to die. Other reasons had to do with being able to lead a normal life or for the quality of the services received at the institution. Some reported having adequate follow-up because they were aware of their disease, grateful to have ART free of charge, or because of responsibility. These findings are particularly relevant, as no studies have been found, especially in this context, on the reasons that motivated patients to maintain adequate follow-up, and these can be used when developing interventions to improve clinical follow-up.
Participants also discussed the impact the pandemic had on their medical follow-up. It evidently had negative consequences, such as limited clinical follow-up where there were no face-to-face clinical consultations or the number of studies performed was scarcer. Difficulties in missing work, problems with confinement measures or even having become ill with COVID-19 were also reported. However, it is interesting to find that the pandemic not only had a negative impact, but was also perceived as positive, especially in people with adequate follow-up, and who had no other conditions or problems to deal with. Since an appointment system was implemented, which made the delivery of medication and appointments to draw blood tests better organized, people reported that medical attention was faster, there were fewer patients in the clinic, or that they even had to visit the clinic less often since they were given ART for a longer period of time and their appointments were scheduled on the same day. It would be important to evaluate the possibility of implementing these procedures in the long term, even after the pandemic, because although they seem to be very effective, they require an important amount of human resources to contact patients and make their appointments, however, this can be an opportunity to design automatic systems to keep track of regular patients, such as SMS messages, email reminders of appointments.

This study has some limitations, the main one is the sample size, which makes it difficult to establish significant relationships and generalize the results; thus, results should be framed in the situation and the moment in which they were collected and can be generalized as long as they are in contexts with the same characteristics. That is, taking into account that the institution from which these findings emerge was located in a hospital that, since the pandemic, exclusively cared for COVID-19 patients and had to discontinue its face-to-face care for PLWH. On the other hand, many other variables can affect such a complex behavior as clinical follow-up and that could not be addressed in this study but should be addressed in future studies, such as time since lost to follow up, whether people voluntarily returned to care or were previously located by the institution, or migration to other institutions due to changes in insurance systems. The latter has been reported as a complicated process that can lead to the abandonment of follow-up [43, 50]. This was reported incidentally in the interviews but could not be measured systematically. In addition, difficulties to locate a large proportion of patients, as well as achieving completion of the questionnaires [41], especially the group of patients with follow-up failures, may contribute to biases in the results observed. However, for an exploratory study, the patient interviews allowed us to detect interesting reasons for missed appointments, or even the reasons that motivated them to have an adequate follow-up, as well as the impact that the pandemic had on this population. 
Some implications can be derived from these results, we observe that structural barriers such as educational level, economic and work-related problems, time of transportation to the clinic are factors that can interfere with adequate attendance at health services. Despite these variables are very difficult to modify, it is important that patients in whom these risk factors are identified can be followed up more closely and that tailored interventions are designed to better address these difficulties and support patients financially, for example in terms of transportation or delivery of medicines, or ensure that they can receive quality care in places closer to their homes, having mobile services and reach out interventions, job boards to PLWH, etc. [51, 52] On the other hand, it is important to closely monitor patients with a history of previous dropouts, and/or inadequate adherence to antiretroviral treatment since these situations may result in definite loss to follow-up or even death [53]. In addition, personalized care, medical staff with time availability, enhancing communication between patients and institutions, and improving information recording systems can favor patient retention [54]. Also, the implemented appointment system was shown to be beneficial especially for those patients who do not need such a close follow-up, so the possibility of keeping this option over time should be considered. Finally, the development of educational programs that inform patients about HIV and ART, and that answer patients' doubts can be a cost-effective strategy, since it can be conducted in group workshops, or through informative brochures, and may contribute to sustaining better medical follow-up and better selfcare behaviors.

\section{Conclusions}

Although these results may not be completely generalizable, due to the small sample size, especially of the group with follow-up failures, and possible selection biases, they are still relevant to this population at the specific and unique moment in which they were obtained. Nevertheless, further studies are needed to better understand the impact of these variables on clinical follow-up. Understanding loss to follow-up in PLWH, which has been less studied than adherence to pharmacological treatment, is especially relevant because of the individual and public health consequences involved. Knowledge of variables influencing clinical follow-up may contribute to early identification of those who are at higher risk of loss to follow up; furthermore, to design specific psychological/behavioral interventions both for the prevention of failure and the rescue of those who are no longer linked to care. In addition, knowing firsthand the reasons that influence the loss of clinical appointments, or the motivation to have an adequate follow-up, provides a comprehensive and deeper understanding of the phenomenon and the needs of the population. Finally, acknowledging the impact of the COVID-19 pandemic on follow-up can help to establish effective procedures and strategies to reduce its negative impact on a vulnerable population such as PWLH.

Acknowledgements The article was carried out as part of the $\mathrm{PhD}$ of the first author under advisorship of the last in Salud Mental Pública of Programa de Maestría y Doctorado en Ciencias Médicas, Odontológicas y de la Salud of Facultad de Medicina of Universidad Nacional Autónoma de México, which had a Conacyt Grant (Registration Number Fellow 698506). The authors would like to thank Dr. Juan José Sanchez-Sosa, Dr. Rebeca Robles, Dr. Corina Benjet, Dr. Gustavo Reyes-Terán and Graciela Guzmán Valdez for their support during the development of the project.

Author Contributions EGV: design of the study; collection, analysis and interpretation of the data and writing of the article. APM: critical review and contributions to the content of the article. SÁR: critical review and contributions to the content of the article. NPCS: design and supervision of the study; writing and critical review of the article.

Funding The study was supported by a CONACyT Grant (Registration Number Fellow 698506).

Data Availability The complete database is available on figshare. https://doi.org/10.6084/m9.figshare.16702933.v1.

Code Availability Not applicable.

Material Availability The complete database is available on figshare. https://doi.org/10.6084/m9.figshare.16702933.v1.

\section{Declarations}

Conflict of interest The authors have no conflict of interest to declare that are relevant to the content of this article.

Ethical Approval The protocol was approved by the Ethics and Research Committee of Instituto Nacional de Enfermedades Respiratorias, under number $\mathrm{C} 02-20$. The procedures used in this study adhere to the tenets of the Declaration of Helsinki.

Consent to Participate All participants gave their consent to participate in the study after learning about its characteristics. Verbal consent was approved due to the restrictions caused by the COVID-19 pandemic and to preserve the safety of participants and investigators.

Consent for Publication Not applicable.

\section{References}

1. Brinkhof MW, Pujades-Rodriguez M, Egger M. Mortality of patients lost to follow-up in antiretroviral treatment programmes in resource-limited settings: systematic review and meta-analysis. PLoS ONE. 2009;4(6):e5790.

2. Almeida MC, de Jesus Pedroso N, do Socorro Lina van Keulen M, Jácome GPO, Fernandes GC, Yokoo EM, et al. Loss to follow-up in a cohort of HIV-infected patients in a regional referral outpatient clinic in Brazil. AIDS Behav. 2014;18(12):2387-96. 
3. Gebrezgabher BB, Kebede Y, Kindie M, Tetemke D, Abay M, Gelaw YA. Determinants to antiretroviral treatment nonadherence among adult HIV/AIDS patients in northern Ethiopia. AIDS Res Ther. 2017;14:16.

4. Mugavero MJ, Davila JA, Nevin CR, Giordano TP. From access to engagement: measuring retention in outpatient HIV clinical care. AIDS Patient Care STDS. 2010;24(10):607-13.

5. CENSIDA. Informe nacional de avances en la respuesta al VIH y el SIDA. Mexico: Secretaria de Salud; 2016.

6. Akilimali PZ, Musumari PM, Kashala-Abotnes E, Kayembe PK, Lepira FB, Mutombo PB, et al. Disclosure of HIV status and its impact on the loss in the follow-up of. PLoS ONE. 2017;12(2):e0171407.

7. Alaniz Cuevas D. Tasa de pérdida en el seguimiento de pacientes VIH positivos en la Clínica Especializada Condesa, Ciudad de México. Factores asociados y consecuencias de la pérdida. [Ciudad de Mexico]: Universidad Nacional Autónoma de México; 2014.

8. De Boni RB, Peratikos MB, Shepherd BE, Grinsztejn B, Cortés $\mathrm{C}$, Padgett D, et al. Is substance use associated with HIV cascade outcomes in Latin America? PLoS ONE. 2018;13(3):e0194228.

9. Aliyu A, Adelekan B, Andrew N, Ekong E, Dapiap S, MurtalaIbrahim F, et al. Predictors of loss to follow-up in art experienced patients in Nigeria: a 13 year review (2004-2017). AIDS Res Ther. 2019;16(1):30.

10 Bezabhe WM, Chalmers L, Bereznicki LR, Peterson GM, Bimirew MA, Kassie DM. Barriers and facilitators of adherence to antiretroviral drug therapy and retention in care among adult HIV-positive patients: a qualitative study from Ethiopia. PLoS ONE. 2014;9(5):e97353.

11. Lankowski AJ, Siedner MJ, Bangsberg DR, Tsai AC. Impact of geographic and transportation-related barriers on HIV outcomes in Sub-Saharan Africa: a systematic review. AIDS Behav. 2014;18(7):1199-223.

12. Herrera C, Campero L, Caballero M, Kendall T. Relación entre médicos y pacientes con VIH: influencia en apego terapéutico y calidad de vida. Rev Saúde Pública. 2008;42(2):249-55.

13 Kuznetsova AV, Meylakhs AY, Amirkhanian YA, Kelly JA, Yakovlev AA, Musatov VB, et al. Barriers and facilitators of HIV care engagement: results of a qualitative study in St. Petersburg, Russia. AIDS Behav. 2016;20(10):2433-43.

14. Cichowitz C, Maraba N, Hamilton R, Charalambous S, Hoffmann CJ. Depression and alcohol use disorder at antiretroviral therapy initiation led to disengagement from care in South Africa. PLoS ONE. 2017;12(12):e0189820.

15 Nogueda-Orozco MJ, Fresán-Orellana A, Vite-Sierra A, Sánchez-Sosa JJ, Sierra-Madero JG, Robles-García R. Escala de apreciación cognitiva del VIH/SIDA: adaptación y evaluación psicométrica en población mexicana. Psicología Iberoamericana. 2016;2016:7.

16. Yehia BR, Stewart L, Momplaisir F, Mody A, Holtzman CW, Jacobs LM, et al. Barriers and facilitators to patient retention in HIV care. BMC Infect Dis. 2015;15(1):246.

17. WHO. WHO Coronavirus (COVID-19) Dashboard [Internet]. 2021. Accessed from https://covid19.who.int

18. Centers for Disease Control and Prevention. People Who Are at Higher Risk for Severe Illness. 2020. https://www.cdc.gov/ coronavirus/2019-ncov/need-extra-precautions/people-withmedical-conditions.html. Accessed 17 May 2021

19. Centers for Disease Control and Prevention. Guidance for COVID-19 and People with HIV [Internet]. 2021. Accessed from https://clinicalinfo.hiv.gov/en/guidelines/covid-19-andpersons-hiv-interim-guidance/interim-guidance-covid-19-andpersons-hiv

20. Dandachi D, Geiger G, Montgomery MW, Karmen-Tuohy S, Golzy M, Antar AAR, et al. Characteristics, Comorbidities, and
Outcomes in a Multicenter Registry of Patients with HIV and Coronavirus Disease-19. Clin Infect Dis. 2020;73:e1694.

21. Brooks SK, Webster RK, Smith LE, Woodland L, Wessely S, Greenberg N, et al. The psychological impact of quarantine and how to reduce it: rapid review of the evidence. Lancet. 2020;395(10227):912-20.

22 Fernandes N. Economic effects of coronavirus outbreak (COVID19) on the world economy. SSRN J. 2020. https://doi.org/10.2139/ ssrn. 3557504 .

23. Ballivian J, Alcaide ML, Cecchini D, Jones DL, Abbamonte JM, Cassetti I. Impact of COVID-19-related stress and lockdown on mental health among people living with HIV in Argentina. J Acquir Immune Defic Syndr. 2020;85(4):475-82.

24. Rubin GJ, Wessely S. The psychological effects of quarantining a city. BMJ. 2020;368:m313.

25. Czeisler MÉ, Marynak K, Clarke KEN, Salah Z, Shakya I, Thierry $\mathrm{JM}$, et al. Delay or avoidance of medical care because of COVID19-related concerns-United States, June 2020. MMWR Morb Mortal Wkly Rep. 2020;69(36):1250-7.

26. Kalichman SC, Eaton LA, Berman M, Kalichman MO, Katner $\mathrm{H}$, Sam SS, et al. Intersecting pandemics: impact of SARSCoV-2 (COVID-19) protective behaviors on people living with HIV, Atlanta, Georgia. J Acquir Immune Defic Syndr. 2020;85(1):66-72.

27. Ridgway JP, Schmitt J, Friedman E, Taylor M, Devlin S, McNulty $\mathrm{M}$, et al. HIV care continuum and COVID-19 outcomes among people living with HIV during the COVID-19 pandemic, Chicago. IL AIDS Behav. 2020;24(10):2770-2.

28. Ayittey FK, Ayittey MK, Chiwero NB, Kamasah JS, Dzuvor C. Economic impacts of Wuhan 2019-nCoV on China and the world. J Med Virol. 2020;92(5):473-5.

29. Jiang H, Zhou Y, Tang W. Maintaining HIV care during the COVID-19 pandemic. Lancet HIV. 2020;7(5):e308-9.

30. Grimsrud AT, Cornell M, Egger M, Boulle A, Myer L. Impact of definitions of loss to follow-up (LTFU) in antiretroviral therapy program evaluation: variation in the definition can have an appreciable impact on estimated proportions of LTFU. J Clin Epidemiol. 2013;66(9):1006-13.

31. Little SJ, Holte S, Routy J-P, Daar ES, Markowitz M, Collier $\mathrm{AC}$, et al. Antiretroviral-drug resistance among patients recently infected with HIV. N Engl J Med. 2002;347(6):385-94.

32. Carriquiry G, Fink V, Koethe JR, Giganti MJ, Jayathilake K, Blevins M, et al. Mortality and loss to follow-up among HIVinfected persons on long-term antiretroviral therapy in Latin America and the Caribbean. J Int AIDS Soc. 2015;18(1):20016.

33 SolerClaudín C. Acceso universal al programa de VIH/SIDA de la Ciudad de México: resultados a seis años. Salud Pública Méx. 2009. https://doi.org/10.1590/S0036-36342009000100007.

34. Robles-García R, Varela R, Jurado S, Páez F. Versión mexicana del inventario de ansiedad de beck: propiedades psicométricas. Revista Mexicana de Psicología. 2001;18(2):211-8.

35. González DA, Reséndiz A, Reyes-Lagunes I. Adaptation of the BDI-II in Mexico. Salud Ment. 2015;38(4):237-44.

36. Anderson D. Development of the trust in physician scale: a measure to assess interpersonal trust in physician relationships. Psychol Rep. 1990;67:1091-100.

37. TiburcioSainz M, Rosete-Mohedano MG, Natera Rey G, Martinez Velez NA, Carreno Garcia S, Perez CD. Validity and reliability of the alcohol, smoking, and substance involvement screening test (ASSIST) in University students. Adicciones. 2016;28(1):19-27.

38. Berger BE, Ferrans CE, Lashley FR. Measuring stigma in people with HIV: psychometric assessment of the HIV stigma scale. Res Nurs Health. 2001;24(6):518-29.

39. MartínezBasurto AE, Sánchez Román S, Aguilar Villalobos EJ, Rodríguez Pérez V, Riveros RA. Adaptación y validación del cuestionario MOS de apoyo social en pacientes mexicanos 
VIH+. Revista Latinoamericana de Medicina Conductual. 2014;4(2):93-101.

40. Horne R, Weinman J, Hankins M. The beliefs about medicines questionnaire: the development and evaluation of a new method for assessing the cognitive representation of medication. Psychol Health. 1999;14(1):1-24.

41. Cardel MI, Manasse S, Krukowski RA, Ross K, Shakour R, Miller DR, et al. COVID-19 impacts mental health outcomes and ability/ desire to participate in research among current research participants. Obesity. 2020;28(12):2272-81.

42. Kranzer K, Govindasamy D, Ford N, Johnston V, Lawn SD. Quantifying and addressing losses along the continuum of care for people living with HIV infection in sub-Saharan Africa: a systematic review. J Int AIDS Soc. 2012;15(2):17383-17383.

43 Udeagu C-CN, Webster TR, Bocour A, Michel P, Shepard CW. Lost or just not following up: public health effort to re-engage HIV-infected persons lost to follow-up into HIV medical care. AIDS. 2013;27(14):2271-9.

44 Támara-Ramírez JR, Álvarez CA, Rodríguez J. Pérdida de seguimiento y factores asociados en pacientes inscritos en el programa de HIV/sida del Hospital Universitario San Ignacio, Colombia, 2012-2013. Biomedica. 2016;36(2):265.

45. Byrd KK, Furtado M, Bush T, Gardner L. Evaluating patterns in retention, continuation, gaps, and re-engagement in HIV care in a Medicaid-insured population, 2006-2012, United States. AIDS Care. 2015;27(11):1387-95.

46. Westergaard RP, Hess T, Astemborski J, Mehta SH, Kirk GD. Longitudinal changes in engagement in care and viral suppression for HIV-infected injection drug users. AIDS. 2013;27(16):2559-66.

47. Yu Y, Luo D, Chen X, Huang Z, Wang M, Xiao S. Medication adherence to antiretroviral therapy among newly treated people living with HIV. BMC Public Health. 2018;18(1):825.
48. Lee S, Lee SH, Lee SJ, Kim K-H, Lee JE, Cho H, et al. Predictors of poor retention in care of HIV-infected patients receiving antiretroviral therapy in Korea: five-year hospital-based retrospective cohort study. J Korean Med Sci. 2016;31(3):376-81.

49. Moctezuma Navarro D, Narro Robles J, Orozco HL. La mujer en México: inequidad, pobreza y violencia. Revista Mexicana de Ciencias Políticas y Sociales. 2014;59(220):117-46.

50. Nordentoft PB, Engell-Sørensen T, Jespersen S, Correia FG, Medina C, da Silva TD, et al. Assessing factors for loss to follow-up of HIV infected patients in Guinea-Bissau. Infection. 2017;45(2):187-97.

51. Bassett IV, Wilson D, Taaffe J, Freedberg KA. Financial incentives to improve progression through the HIV treatment cascade. Curr Opin HIV AIDS. 2015;10(6):451-63.

52. Munson AJ, Davis DA, Barrington C. 'There are no other options for us because of who we are': employment and retention in care among gay and bisexual men and transgender women living with HIV in Guatemala. Cult Health Sex. 2021;23(5):608-23.

53. Braitstein P, Siika A, Hogan J, Kosgei R, Sang E, Sidle J, et al. A clinician-nurse model to reduce early mortality and increase clinic retention among high-risk HIV-infected patients initiating combination antiretroviral treatment. J Int AIDS Soc. 2012;15:7.

54 Mallinson RK, Rajabiun S, Coleman S. The provider role in client engagement in HIV Care. AIDS Patient Care STDs. 2007;21(s1):S-77.

Publisher's Note Springer Nature remains neutral with regard to jurisdictional claims in published maps and institutional affiliations. 